\title{
Pharmaciana
}

Vol.9, No.1, May 2019, Page. $41-46$

ISSN: 2088 4559; e-ISSN: 24770256

DOI: 10.12928/pharmaciana.v9i1.11902

\section{Antioxidant and alpha-amylase inhibitory study of Sansevieria trifasciata Prain. leaves extract}

\author{
Vivi Anggia*, Lusi Putri Dwita, Istikomah \\ Faculty of Pharmacy and Science, Universitas Prof. DR. HAMKA (UHAMKA) \\ Islamic Center Delima Raya II/IV Street, Perumnas Klender, Jakarta Timur
}

Submitted: 26-11-2019

Reviewed: 26-11-2019

Accepted: 22-04-2019

\begin{abstract}
Diabetes is one of the chronic diseases whose prevalence is increasing all over the world, including in Indonesia. Diabetes mellitus is characterized by high blood glucose levels that can be overcome by, for instance, inhibiting the alpha-amylase enzymes that play a role in carbohydrate hydrolysis. Several studies have proved that active antioxidant substances can also support the treatment of diabetic patients. Snake plant (Sansevieria trifasciata Prain.), or locally known as lidah mertua in Indonesia, is a traditional herbal used to treat diabetes. This study investigated the activity of the ethanol extract of $S$. trifasciata leaves in inhibiting $\alpha$-amylase. The leaves were extracted by maceration with ethanol $70 \%$, followed by phytochemical screening. The antioxidant activity was determined using the DPPH method, while the inhibition of $\alpha$-amylase was measured using UV-Vis spectrophotometer at $524 \mathrm{~nm}$ wavelength. The results showed that $\mathrm{IC}_{50}$ of the antioxidant activity was $1527.55 \mathrm{ppm}$, five times greater than the positive control, i.e., vitamin C. In the case of $\alpha$-amylase enzyme, the $\mathrm{IC}_{50}$ of the ethanol extract of $S$. trifasciata leaves was $158.31 \mu \mathrm{g} / \mathrm{ml}$ and 0.26 times more potential than acarbose. The study has proved that the crude extract of $S$. trifasciata leaves has the potential as one of the antidiabetics and antioxidants that can be studied further.
\end{abstract}

Keywords: Sansevieria trifasciata Prain., $\alpha$-amylase, antidiabetic

\footnotetext{
*Corresponding Author:

Vivi Anggia

Faculty of Pharmacy and Science, Universitas Prof. DR. HAMKA

Islamic Center Delima Raya II/IV Street, Perumnas Klender, Jakarta Timur

Email: vivi.anggia@gmail.com
} 


\section{INTRODUCTION}

Diabetes mellitus is one of the major chronic diseases and predominant health problems worldwide, including Indonesia. The data from the Indonesian Endocrinology Society states that the number of people with diabetes mellitus in Indonesia reached 9.1 million people in 2015 (PERKENI, 2015). Among countries with the largest population size in the world, Indonesia has moved up from the seventh rank to the top 5 countries with high diabetes mellitus incidence. Such a high prevalence proves that it is a severe public health problem, and diabetic patients are therefore in need of proper treatment.

Diabetes mellitus is characterized by high blood glucose levels that can be overcome by, one of which, inhibiting digestive enzymes such as $\alpha$-amylase and $\alpha$-glucosidase that play a role in the hydrolysis of carbohydrates. Digested carbohydrates are absorbed by the wall of the small intestines in the form of monosaccharides (Lee et al., 2010). Diabetes is differentiated based on the cause of the disease. Type 1 is usually attributable to the failure to produce insulin as a result of the destruction of beta cells or abnormal secretion of some hormones in the blood that act as an antagonist to insulin. Hence, the study of antidiabetic through their ability to inhibit the alpha-amylase activity has been increasingly conducted by many researchers. Wickramaratne et al. (2016) have reported that Adenanthera pavonina, a plant used as a diabetic treatment in Ayurvedic Medical system in Sri Lanka, has inhibitory properties against alpha-amylase. The leaf extract of Tithonia diversifolia, one of the plants used as antidiabetic herbal tea in Japan, has been proven to reduce blood glucose levels in diabetic mice and impede $\alpha$-amylase activity (Miura et al., 2005; Fitrianingsih et al., 2016).

Several studies have revealed the correlation between antioxidant and antidiabetic activities of numerous natural products. Antioxidants act as scavengers because they prevent cell and tissue damage by stopping or retarding oxidation (Findik et al., 2011). For instance, the ethanol extract of Elaeocarpus ganitrus bark has not only $\alpha$-amylase inhibitory properties but also antioxidant potential (Talukdar et al., 2017). Furthermore, the aqueous extract of Cassia occidentalis has been documented to exhibit significant antihyperglycemic effect in alloxan-induced diabetic rats through regenerating pancreatic $\beta$-cells with $84.23 \%$ DPPH inhibition.

Sansevieria trifasciata, or locally known as lidah mertua, is widely spread in various regions in Indonesia. S. trifasciata is a common perennial that wildly grows and is commonly found in residential areas, parks, and woodlands predominantly as ornamental plants (Rwawiire and Blanka, 2015). It is extensively used in the traditional remedies of various diseases, for instance, diabetes. Several studies about its antidiabetic activity have reported the effect of its leaves in lowering blood glucose levels. The ethanolic extract of $S$. trifasciata can decrease blood glucose levels in sucrose-induced diabetes in rats at a dose of $0.083 \mathrm{~g} / \mathrm{kg} \mathrm{BW}$ (Laimeheriwa et al., 2014). The decoction of the leaves can reduce blood glucose levels of alloxan-induced rats at a dose of $150 \mathrm{mg} / \mathrm{kg} \mathrm{BW}$ (Qomariyah, 2012), but its mechanism to decrease the glucose levels has not been examined. This study reported the antioxidant activities and the $\alpha$-amylase inhibitory properties of the ethanol extract of $S$. trifasciata Prain. leaves. The antioxidant activity was examined with the DPPH method (Molyneux, 2004), while the $\alpha$-amylase inhibition was identified using a DNS (dinitrosalicylate) reagent (Thalapaneni et al., 2008).

\section{MATERIALS AND METHOD}

\section{Materials}

The S. trifasciata Prain. leaves were obtained from the Indonesian Institute of Spices and Medicinal Plants Research (BALITRO), Bogor. The plant determination was conducted at Herbarium Bogoriense, LIPI, Bogor. The alpha-amylase enzyme came from Bacillus licheniformis (SigmaAldrich). 


\section{Methods}

\section{Extraction}

One kg of S. trifasciata Prain. leaf powder was macerated with $10 \mathrm{~L}$ of ethanol $70 \%$ for three days. After filtering the extract, the process was repeated three times. The extracts from this replication were combined and subjected to vacuum evaporation to produce $184.94 \mathrm{~g}$ of a concentrated extract.

\section{Phytochemical Screening}

The concentrated extract $(50 \mathrm{mg}$ ) was diluted using ethanol and tested for the presence of alkaloid, flavonoid, tannin, terpene, and steroid (Harborne, 1987).

\section{Antioxidant Properties}

Two $\mathrm{mg}$ of DPPH was dissolved in $100 \mathrm{ml}$ of $\mathrm{MeOH}$, then $3.8 \mathrm{ml}$ of DPPH solution was added with $0.2 \mathrm{~mL}$ of $\mathrm{MeOH}$ and left for 30 minutes in the dark. Then, this solution was scanned with a UVVis spectrophotometer (400-800 $\mathrm{nm}$ wavelengths) to obtain the wavelength of maximum absorbance $\left(\lambda_{\max }\right)$. Each sample was diluted with $\mathrm{MeOH}$ to prepare extracts with concentrations of $100,150,200$, 250 , and $300 \mathrm{ppm}$. Using a pipette, $0.2 \mathrm{~mL}$ of each extract was taken and mixed with $3.8 \mathrm{~mL}$ of DPPH solution. The absorbance of the sample was measured at $\lambda_{\max }$ for 30 minutes. The data obtained from this procedure were processed with the formula below (Molyneux, 2004). Vitamin C was used as the positive control.

$$
\% \text { Inhibition }=\mathrm{I}(\%)=\left[1-\left(\mathrm{A}_{517} \text { sample } / \mathrm{A}_{517} \text { control }\right)\right] \times 100 \%
$$

The $\mathrm{IC}_{50}$ was calculated using the regression equation, then the AAI (Antioxidant Activity Index) was calculated to determine the antioxidant level of the sample. Antioxidant properties based on AAI are presented in Table I (Scherer and Godoy, 2009).

$\mathrm{AAI}=$ Final concentration of DPPH $(\mu \mathrm{g} / \mathrm{ml}) / \mathrm{IC}_{50}(\mu \mathrm{g} / \mathrm{mL})$

Table I. Antioxidant properties based on Antioxidant Activity Index (Scherer and Godoy, 2009)

\begin{tabular}{cc}
\hline AAI values & Antioxidant properties \\
\hline$>2.0$ & Very strong \\
$1.0-2.0$ & Strong \\
$0.5-1.0$ & Moderate \\
$<0.5$ & Weak \\
\hline
\end{tabular}

\section{$\alpha$-amylase inhibition assay}

The $\alpha$-amylase inhibitory activity was determined using a published test method in Thalapaneni et al. (2008), with modification. The test samples (90, 150, 260, 450, and $780 \mathrm{ppm})$ and acarbose (16, $25,39,61,95$, and $150 \mathrm{ppm}$ ) were combined, amounting to $500 \mu \mathrm{L}$, and placed in tubes containing $500 \mu \mathrm{L}$ of $\alpha$-amylase solution $(0.5 \mathrm{ppm})$ in $0.02 \mathrm{M}$ phosphate buffer ( $\mathrm{pH} 6.9$ with $0.006 \mathrm{M} \mathrm{NaCl}$ ), then incubated at $25^{\circ} \mathrm{C}$ for 10 minutes. Each tube was then added with $500 \mu \mathrm{L}$ of $1 \%(\mathrm{~b} / \mathrm{v})$ of starch solution in $0.02 \mathrm{M}$ phosphate buffer at the time interval, then incubated at $25^{\circ} \mathrm{C}$ for 10 minutes. After the second incubation, the reaction was stopped with $1000 \mu \mathrm{L}$ of dinitrosalicylic acid (DNS) reagents. The tubes were then incubated in a boiling water bath for 5 minutes, then cooled to room temperature. Afterward, $10,000 \mu \mathrm{L}$ of distilled water was added to the reaction mixture and measured at $524 \mathrm{~nm}$.

\section{RESULTS AND DISCUSSION}

\section{Phytochemical screening}

The results showed that the $S$. trifasciata leaf extract contained alkaloid, flavonoid, tannin, saponin, and steroid. 


\section{Antioxidant activity of $S$. trifasciata leaf extract}

In-vitro antioxidant activity of $S$. trifasciata was performed with DPPH radical scavenging method, as described by Molyneux (2004). The samples were measured at $517 \mathrm{~nm}$, the $\lambda_{\max }$ of DPPH. DPPH has a strong absorbance, i.e., 0.743 , at $517 \mathrm{~nm}$ due to its dark violet colors. Free radical scavengers cause electrons to form pairs, which then triggers color removal that is proportional to the number of electrons taken and to the antioxidant activity of the sample (Sunarni et al., 2007). The antioxidant properties of the S. trifasciata leaf extract are presented in Table II.

Table II. Antioxidant properties of $S$. trifasciata leaf extract (SLE)

\begin{tabular}{lccc}
\hline Samples & $\begin{array}{c}\text { Concentrations } \\
(\mathbf{p p m})\end{array}$ & Inhibition $\mathbf{( \% )}$ & $\begin{array}{c}\mathbf{I C}_{\mathbf{5 0}} \\
(\mathbf{p p m})\end{array}$ \\
\hline SLE & 100 & 6.24 & 1527.55 \\
& 150 & 6.91 & \\
& 200 & 7.72 & \\
& 250 & 8.80 & \\
\hline Vitamin & 300 & 13.10 & \\
C & 2 & 91.66 & 308.91 \\
& 3 & 91.80 & \\
& 4 & 91.93 & \\
& 5 & 92.06 & \\
\hline
\end{tabular}

The \%IC was used to obtain linear regression equations. These equations help to identify at which concentration the $S$. trifasciata leaf extract can effectively reduce DPPH free radicals or $\mathrm{IC}_{50}$ values. The $\mathrm{IC}_{50}$ is represented by the $x$ value, which was obtained by substituting 50 for the $y$ value.

The assays showed that the $\mathrm{IC}_{50}$ value of the crude extract of $S$. trifasciata leaves was five times greater than that of vitamin $\mathrm{C}$ (positive control), and the AAI was 0.0124 , indicating weak antioxidant activity. Nevertheless, a further examination of the antioxidant activity of the bioactive compounds in the $S$. trifasciata leaf extract is still possible to perform (Table II).

\section{$\alpha-$ amylase inhibitory activity}

Inhibition of postprandial metabolism by impeding $\alpha$-amylase enzyme is one way to treat hyperglycemia in diabetic patients. In this case, the digestion of carbohydrate can be inhibited, and therefore the blood glucose level can be reduced. This test was conducted to determine the decrease in blood glucose level. Carbohydrates are converted into glucose and maltose that will react with DNS (3,5-dinitrosalicylic) and produce color. The activity of the $\alpha$-amylase enzyme was measured based on the absorbance of DNS. The more reactions that occur between maltose and glucose with DNS will result in reddish-orange color and higher sample absorbance. On the contrary, if the extract can inhibit the $\alpha$-amylase enzyme, then the hydrolysis of the starch will be reduced, resulting in lower maltose and absorbance. The alpha-amylase inhibitory properties of $S$. trifasciata leaf (SLE) extract and acarbose are presented in Table III. The results showed that the $\mathrm{IC}_{50}$ of the crude extract exhibited $\alpha$ amylase inhibitory activity with $\mathrm{IC}_{50}=158.31 \mathrm{ppm}$. The $\mathrm{IC}_{50}$ value of the standard positive control, acarbose, was $42.7 \mathrm{ppm}$. 
Table III. Alpha-amylase inhibition activities of $S$. trifasciata leaves (SLE) extract and acarbose

\begin{tabular}{cccc}
\hline Samples & $\begin{array}{c}\text { Concentrations } \\
(\mathbf{p p m})\end{array}$ & Inhibition $(\boldsymbol{\%})$ & $\mathbf{I C}_{\mathbf{5 0}}(\mathbf{p p m})$ \\
\hline SLE & 90 & 36.88 & 158.31 \\
& 150 & 48.67 & \\
& 260 & 60.46 & \\
& 450 & 74.90 & 42.7 \\
\hline Acarbose & 780 & 87.07 & \\
& 16 & 21.3 & \\
& 25 & 29.7 & \\
& 39 & 46.4 & \\
& 61 & 57.8 & \\
& 95 & 77.2 & \\
\hline
\end{tabular}

The use of herbal medicine as a source of therapy for various diseases has increased continuously, including for diabetes treatment. Although many antidiabetic drugs have been proven effective, herbal medicines are still in high demand because of their lower prices and relatively fewer side effects.

This study observed the antidiabetic activity of the crude extract by examining its ability as an active antioxidant and inhibitor of the alpha-amylase enzyme activity. The alpha-amylase enzyme contributes to the digestion of carbohydrates into monosaccharides that will be absorbed by the wall of the small intestines (Lee et al., 2010). The pathogenesis of diabetes mellitus includes oxidative stress, one of the causes of free radicals and reactive oxygen species (ROS). These two oxygen forms can occur under normal physiological conditions, and unless eliminated appropriately, they can be harmful (Pattanayak et al., 2011). Furthermore, a significant increase in endogenous prooxidant activity and a decrease in antioxidant have been shown to contribute to the oxidative stress in diabetes (Nasri and Rafieian-Kopaei, 2013). Diabetic complications are likely to occur as a result of oxidative stress because of the formation of free radicals by glucose oxidation and the subsequent oxidative degradation of the glycated protein (Mehta et al., 2006).

By actively searching for plants that have the potential as active antioxidants and inhibitors of $\alpha$ amylase enzymes, cell damage can be prevented, especially pancreatic beta cells that contribute to insulin production and the inhibition of monosaccharides absorption in the gastrointestinal tract. Furthermore, the consumption of antioxidant can support antidiabetic therapy.

\section{CONCLUSION}

Although the crude extract of $S$. trifasciata has weak antioxidant activity, active substances that provide better antioxidant activity can still be isolated. Based on the results of the $\alpha$-amylase inhibitory study of $S$. trifasciata leaf extract, $S$. trifasciata leaves can be one of the candidates for the source of antidiabetic treatment in further study.

\section{ACKNOWLEDGMENT}

Authors would like to acknowledge UHAMKA Research Institution for supporting this work.

\section{REFERENCES}

Findik, E., Ceylan, M., Elmastas, M., 2011. Isoeugenol-based novel potent antioxidants: Synthesis and reactivity. European Journal of Medicinal Chemistry, 46 (9):4618-4624.

Fitrianingsih, S.P., Indra, T.M., Ratu, C., Desirian, D., Ratih, A., 2016. Uji aktivitas penghambatan alfa amilase ekstrak daun Tithonia diversifolia secara in vitro. Prosiding SNaPP, 6 (1). 
Harborne, J.B., 1987. Phytochemical methods. In: applied phytochemistry method. Kosasih, P. and I. Soediro (Eds.). Penerbit ITB, Bandung.

Lee, S.H., Mi-Hwa, P, Soo-Jin, H., Sung-Myung, K., Seok-Chun, K., Ji-Sook, H., You-Jin J., 2010. Dieckol isolated from Ecklonia cava inhibits $\alpha$-glucosidase and $\alpha$-amylase in vitro and alleviates postprandial hyperglycemia in streptozotocin-induced diabetic mice, Food and Chemical Toxicology, 48 (10): 2633-2637.

Miura, T., Nosaka, K., Ishii, H., and Ishida, T., 2005. Antidiabetic effect of nitobegiku, the herb Tithonia diversifolia, in KK-Ay diabetic mice, Biol. Pharm. Bull., 28 (11): 2152-2154.

PERKENI (Perkumpulan Endokrinologi Indonesia), 2015. Pengelolaan dan Pencegahan Diabetes Melitus Tipe 2 di Indonesia 2015. PB PERKENI.

Laimeheriwa, C., Adeanne, C.W., Widya, A.L. 2014. Uji efek ekstrak etanol daun lidah mertua (Sansevieria trifasciata Prain) terhadap penurunan kadar gula darah tikus putih jantan galur wistar (Rattus norvegicus L.). PHARMACON Jurnal Ilmiah Farmasi, 3 (3): 255-262.

Mehta J.L., Rasouli N., Sinha A.K., Molavi B., 2006, Oxidative stress in diabetes: a mechanistic overview of its effects on atherogenesis and myocardial dysfunction. Int J Biochem Cell Biol, 38:794-803

Molyneux, P., 2004. The use of stable free radical diphenylpicrylhydrazyl (DPPH) for estimating antioxidant activity, Songklanakarin J. Sci. Technol, 26(2). 211-219.

Nasri, H., Rafieian-Kopaei M., 2013. Tubular kidney protection by antioxidants, Iran. J. Public. Health, 42: 1194-6.

Pattanayak, S.P., Mazumder, P.M., Sunitha, P., 2011. Total phenolic content, flavonoid content and in vitro antioxidant activities of Dentrophthoe falcate (L.F.) Ettingsh. Int. J. PharmTech Res., 3:1392-1406.

Qomariyah, N., 2012. Antidiabetic effects of a decoction of leaves of Sansevieria trifasciata in alloxan-induced diabetic white rats (Rattus norvegicus L.). ITB J. Sci., 44A (4): 308-316.

Rwawiire. S., Blanka, T., 2015. Morphological, thermal, and mechanical characterization of Sansevieria trifasciata fibers. Journal of Natural Fibers, 12 (3): 201-210.

Scherer, R., Godoy, H. T., 2009. Antioxidant activity index (AAI) by the 2,2-diphenyl-1picrylhydrazyl method, Food Chemistry., 112 (3): 654-658.

Sunarni, T., Pramono, S., Asmah, R., 2007. Flavonoid antioksi dan penangkap radikal dari daun kepel (Stelechocarpus burahol (B1.) Hook f.\& Th.). Majalah Farmasi Indonesia, 18 (3): 111116.

Talukdar, N., Dutta, A.M., Raja, C., Karabi, D., 2017. Screening of phytochemicals, antioxidant and inhibitory effect on alpha-amylase by ethanolic extract of Elaeocarpus Ganitrus (Bark). IJPSR, 8(12):5270-5275.

Thalapaneni, N.R., Chidambran, K.A., Ellappan, T., Sabapathi, M.L., Mandal, S.C., 2008. Inhibition of carbohydrate digestive enzymes by Talinum portulacifolium (Forssk) leaf extract. Journal of Complementary and Integrative Medicine, 5 (1).

Wickramaratne, M.N., Punchihewa, J.C., Wickramaratne, D.B.M., 2016. In-vitro alpha-amylase inhibitory activity of the leaf extracts of Adenanthera pavonina, BMC Complement Altern Med., $16(1): 466$. 